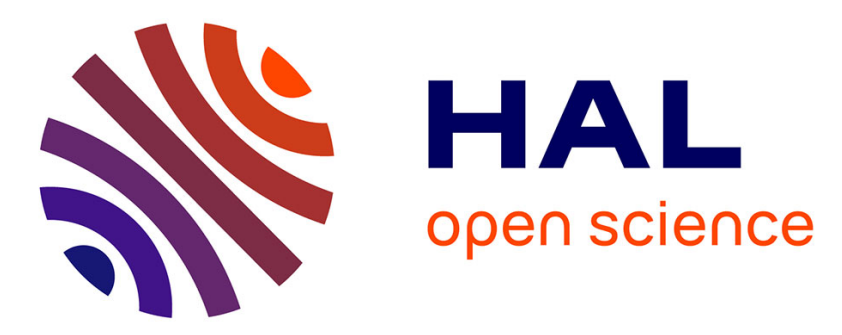

\title{
Achieving universal health coverage in France: policy reforms and the challenge of inequalities
}

Olivier Nay, Sophie Béjean, Daniel Benamouzig, Henri Bergeron, Patrick Castel, Bruno Ventelou

\section{- To cite this version:}

Olivier Nay, Sophie Béjean, Daniel Benamouzig, Henri Bergeron, Patrick Castel, et al.. Achieving universal health coverage in France : policy reforms and the challenge of inequalities. The Lancet, 2016, France: nation and world, 387 Special Series (10034), pp.2236-2249. 10.1016/S0140-6736(16)00580-8 . hal-01314882

\section{HAL Id: hal-01314882 \\ https://hal.science/hal-01314882}

Submitted on 12 May 2016

HAL is a multi-disciplinary open access archive for the deposit and dissemination of scientific research documents, whether they are published or not. The documents may come from teaching and research institutions in France or abroad, or from public or private research centers.
L'archive ouverte pluridisciplinaire HAL, est destinée au dépôt et à la diffusion de documents scientifiques de niveau recherche, publiés ou non, émanant des établissements d'enseignement et de recherche français ou étrangers, des laboratoires publics ou privés. 


\section{THE
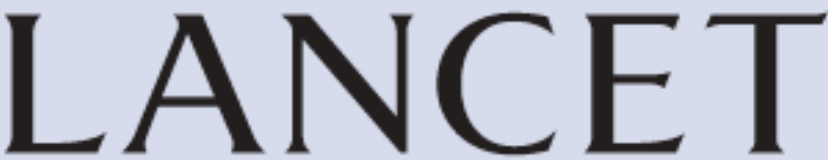

Max, 2016

\section{France: nation and world}

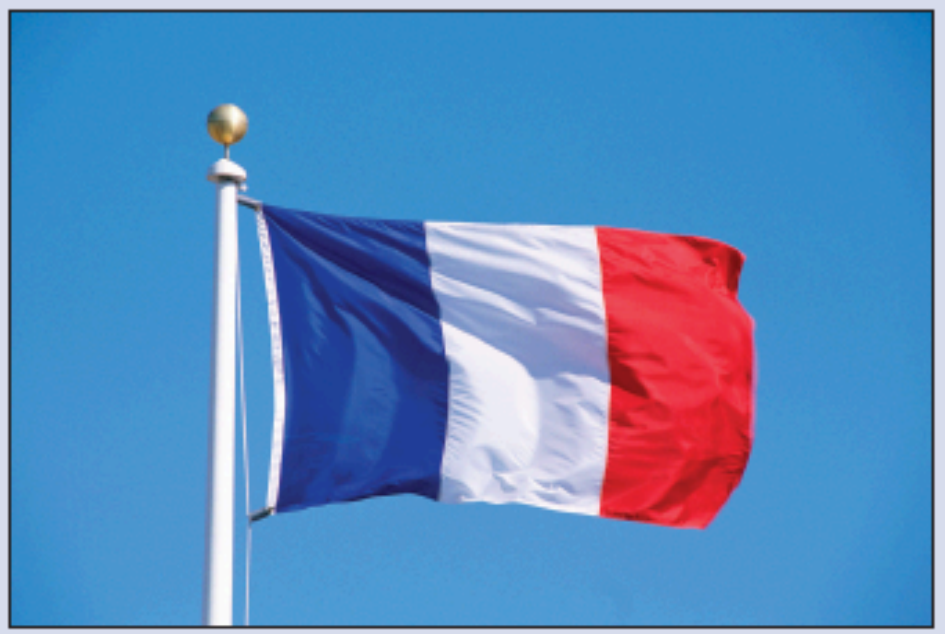

Achieving Universal Health Coverage: Policy Reforms and the Challenge of Inequalities in the French Health System

The Lancet, "France: Nation and World" (Special Series), May 2, 2016

Prof Olivier Nay PhD (corresponding author ${ }^{1}$ ), Prof Sophie Béjean PhD, Prof Daniel Benamouzig PhD, Prof Henri Bergeron PhD, Prof Patrick Castel PhD, Prof Bruno Ventelou $\mathrm{PhD}$

This version is the last stage edited proof (January 2016), prior to final editing.

The final version was published in The Lancet,

Special Series on "France: Nation and World", May 2, 2016. after important editing.

Any quote should refer to the published final version ${ }^{2}$.

\footnotetext{
1 o.nay@free.fr

${ }^{2}$ To get the final version, please click on:

http://www.thelancet.com/journals/lancet/article/PIIS0140-6736\%2816\%2900580-8/fulltext
} 


\section{Abstract:}

Since 1945, the provision of health care in France has been grounded in a social conception promoting universalism and equality. The French health-care system is based on compulsory social insurance funded by social contributions, co-administered by workers' and employers' organisations under State control and driven by highly redistributive financial transfers. This system is described frequently as the French model. In this paper, the first in The Lancet's Series on France, we challenge conventional wisdom about health care in France. First, we focus on policy and institutional transformations that have affected deeply the governance of health care over past decades. We argue that the health system rests on a diversity of institutions, policy mechanisms, and health actors, while its governance has been marked by the reinforcement of national regulation under the aegis of the State. Second, we suggest the redistributive mechanisms of the health insurance system are impeded by social inequalities in health, which remain major hindrances to achieving objectives of justice and solidarity associated with the conception of health care in France. 


\section{Introduction}

Since the end of the World War II, the French healthcare system has evolved as a social project driven by two great principles: universalism and equality. The extension of health insurance coverage over seven decades has made it possible to guarantee everyone access to minimal healthcare. The health insurance system is based on a redistributive philosophy intended to match households' financial contributions to their ability to pay and to guarantee low income individuals access to good quality coverage.

This social conception of health is a feature of the French experience. Its aim is to promote justice and solidarity while ensuring high-quality healthcare. The French model, as it is called often, is based on a national system of health insurance funded by employee and employer social contributions and co-administered by workers' and employers' organisations under State supervision. This model has inspired national reforms in developing countries supported by the French international health assistance ${ }^{1}$. It is set apart most often from other European health protection systems in a reductionist opposition between Bismarckian and Beveridgean social insurance systems.

Our article shows that it is difficult to relegate health governance in France to an institutional archetype. Not only does the French system rely on various policy mechanisms and health actors, it has been transformed profoundly over the past two decades. Changes have affected health financing, healthcare provision and national health strategies monitoring. These have been a result of public administration reforms and reorganisation of labour, management and government bodies involved in health insurance. The role of State institutions in regulating the healthcare system has grown throughout these successive reforms.

The French experience also shows the objectives of universality and equality cannot be met simply by continuously extending health insurance coverage: they also require public efforts to reduce effectively social inequalities in health. Although institutional mechanisms guarantee solidarity in healthcare funding, substantial social disparities continue to maintain inequalities in social groups' access to care. Like most developed Western countries with comparable institutional capacity, the French system, although generous in its principles, still has difficulty reaching its egalitarian objectives. Many determinants of social inequalities in health lie outside the healthcare system (for example, education, social class, and living and working conditions).

The first part of this article shows the French healthcare system relies on a diversity of institutions, policy mechanisms and health actors. State-driven reinforcement of national regulations has been extensive in the past two decades. The second part focuses on redistributive aspects of the French healthcare system. It addresses both funding mechanisms and key factors that may impede the social conception of health. It illustrates 
how certain social determinants are major obstacles to meeting the objectives of universality and equality in access to healthcare.

\section{French healthcare governance: Institutional transformations and policy challenges}

Historically, the French healthcare insurance and delivery system is one that involves state institutions, non-profit groups and the private sector. In recent decades, government regulation has played an increasing role in the French system without, however, centralising it. Firstly, local participants retain substantial autonomy: healthcare professionals have much freedom in their work and are involved in hospital and other healthcare facilities' governance. Patients have the freedom to choose how they access the healthcare system. And secondly, institutional diversity is maintained and local coordination among providers and payers remains insufficient. Today, State reinforcement in its supervision of the health system takes on complex, even hybrid forms. It relies on introducing governmental rules drawn from company management techniques and on what is known as the new public management ${ }^{2}$. It also promotes prevention programs to make individuals more responsible for dealing with their health risks, such as smoking ${ }^{3}$, alcohol ${ }^{4}$ and obesity ${ }^{5}$.

\section{Institutional diversity in the French health system}

In France, hospitals developed most significantly from the $19^{\text {th }}$ century on. At the end of this same century, as assistance laws were passed in Europe, the Third Republic decided in 1893 to guarantee access to healthcare facilities to the poor. Concurrently, collective or private insurance schemes (Sociétés de secours mutuel, Caisses syndicales and Caisses patronales) were launched ${ }^{6}$. However, one might consider the first attempts to establish a system covering healthcare costs in France date back to the statutes that set up the first compulsory social insurance, enacted in 1928 and 1930. Nonetheless, private practitioners' resistance limited implementation. Only at the end of World War II did a new plan emerge. The National Council of the Resistance, which comprised representatives of all political parties, from Communists to Gaullists, set up a complete social insurance system covering healthcare, workplace accidents, old age and family benefits ${ }^{7}$. Since 1945, the French healthcare system has expanded gradually, broadening the population's solidarity-based coverage through other compulsory funds. In 1945, the general social insurance system (Régime général de la sécurité sociale, hereafter the general fund) and its health insurance fund (hereafter the general health insurance fund) were established for the private sector. Several specific funds were added subsequently, most importantly, the social insurance fund for farmers and agricultural workers in 1961 (Mutualité sociale agricole) and the national fund for professionals and independent workers in 1966 (now the Régime social des 
indépendants). Today, around 15 of these funds coexist (e.g., for civil servants, students, the armed forces, seamen, members of the National Assembly, authorised private-practice doctors). In France, employer and employee payroll taxes fund this mandatory coverage. Trade unions and employer organisations (often called the "social partners") administer it jointly and equally. The universality of the solidarity-based coverage was enhanced in 1999 with a system of free access to care. Populations previously excluded from the standard services were included in the general fund and covered by universal basic health insurance (Couverture maladie universelle de base or $\mathrm{CMU}$ ). Subsequently, free universal complementary health insurance was launched to cover co-payments not reimbursed by the compulsory insurance. These notable advances in the compulsory health insurance system often took place during exceptional historic occasions or relied on special legal instruments - decrees (ordonnances) in 1945, 1958, 1967, and 1996, which are legislative texts the government introduces to bypass medical professions' power and lobbying ${ }^{8}$.

\section{Panel - Main Health Reforms in France since 1945}

1945: Creation of the French Sécurité Sociale (Social Security Act).

1958: Major hospital reform, setting the civil servant status for doctors working in public hospitals and creating Teaching hospitals.

1967: Creation of specific risk-related funds, managing health, retirement and family benefits. The management of such funds is given to representatives of both employers and employees.

1970 : Act \#70-1318 establishing policy instruments for rationalising and balancing healthcare delivery across French regions ("carte sanitaire ") and authorising clustering of hospitals.

1984: Funding reform for Public Hospitals: Global budgeting

1991: Act \#91-748 establishing policy instruments for rationalising and balancing healthcare delivery across French regions ("schémas d'organisation sanitaire ») and making compulsory the development of strategic planning for hospitals (" projets d'établissement »)

1996: Legislative decrees ("Ordonnances Juppé ») striving to increase control mechanisms on health expenditure and creating Regional Hospital Agencies (« Agences régionales de I'hospitalisation - ARS ") in charge of healthcare organisation, control and monitoring.

2002: "Loi Kouchner » for the rights of patients and representatives of patients

2004: Law \#2004-810 reorganising, among others, the Health Insurance governance system and law \# 2004-806 for the development of public health policies.

2005: Reform of hospital architecture and governance; Implementation of the French equivalent of the DRG system (« Tarification à l'Activité »). 
2009: Law "Hôpital, patients, santé, territoire "; creation of the Regional Health Agencies ("Agence régionale de la santé »), merging ARS and Social Security regional bureaux; measures fostering coordination of healthcare providers and reinforcing the gate-keeper role of general practitioners in the care pathway.

2015: Loi Touraine (see panel 2)

Nonetheless, this historic movement making health insurance universal in France has not led to the institutionalisation of a State-controlled healthcare system either for health insurance, especially complementary, or for healthcare provision. Despite its affinities with the Bismarckian model ${ }^{9}$, the French model is singular. It has been characterised since 1945 by its diarchic leadership: the joint (i.e., employers and employees) compulsory health insurance system manages "private medicine", while the Ministry of Health manages public hospitals and public health programs. More generally, the French system combines public, non-profit and private institutions and mechanisms and is traditionally characterised by its diversity. Worth noting, the implementation of healthcare laws and policies in overseas departments and territories varies ${ }^{10}$.

Firstly, although it is not a national system, as the British and Scandinavian health systems are, it nonetheless grants a major role to State institutions in the areas of health insurance and healthcare provision. The public sector's role in organising health is considerable, both in the training of doctors (general practitioners and specialists) as in the healthcare public hospitals offer (e.g., regional university hospitals, regional hospitals and local hospitals). From 1950 to 1990, decisions to expand the public care offering increased the number of public hospital beds from 350,000 to 580,000 ; they account today for $65 \%$ of the total.

Secondly, the fundamental principles of the French system are not based on market regulation, as in the United States system. Nonetheless, it gives market players a large role. In health insurance, for example, many private complementary plans bolster the compulsory system and play a key role today in funding the primary care associated with minor risks. A dense network of private clinics provides a substantial share of the healthcare offering. They specialise in certain diseases and treatments, especially surgery with a $45.5 \%$ market share in 2010. Also, especially in outpatient care, the French system is characterised by a large private (self-employed) sector, which accounts for nearly $20 \%$ of national healthcare costs and to which the French turn first when sick, for these are their primary care doctors.

Finally, the French healthcare system has a large non-profit sector: the mutuelles are key players in the complementary insurance business. They defend the principle of solidarity among their subscribers and do not link premiums to subscribers' health risks. To the extent possible, they also avoid selection according to risks. Non-profit healthcare institutions are plentiful, providing nearly 60,000 beds in 2010 . They are funded in a manner similar to 
public hospitals, although private law governs their accounting procedures. Profits are not distributed to shareholders, as in purely private hospitals, but are reinvested in the facility. Nearly all of these facilities are committed officially to upholding French values of equality: every individual has an equal right of access to care and to its continuity and permanence.

Table 1. Main characteristics of healthcare facilities in the public, non-profit and forprofit sectors

\begin{tabular}{|c|c|c|c|}
\hline & Public sector & Non-profit sector & For-profit-sector \\
\hline $\begin{array}{l}\text { Healthcare } \\
\text { organizations }\end{array}$ & $\begin{array}{c}\text { University affiliated } \\
\text { hospitals (CHU-CHR), } \\
\text { General Hospitals } \\
\text { (CHG) }\end{array}$ & $\begin{array}{l}\text { Cancer centers, } \\
\text { Mutualist clinics and } \\
\text { health centers }\end{array}$ & $\begin{array}{c}\text { Clinics, Private medical } \\
\text { offices and medical } \\
\text { groups }\end{array}$ \\
\hline Patient selection & No & No & Yes \\
\hline Specific activities & $\begin{array}{c}\text { Research and } \\
\text { Teaching, Transplants, } \\
\text { Antenatal Diagnostics }\end{array}$ & $\begin{array}{c}\text { None } \\
\text { (Cancer therapy remains } \\
\text { an important activity) }\end{array}$ & None \\
\hline $\begin{array}{l}\text { Number of entities } \\
\text { (2011) }\end{array}$ & 947 & 700 & 1047 \\
\hline Number of beds (2011) & 258.156 & 57.717 & 98.522 \\
\hline $\begin{array}{l}\text { Number of ambulatory } \\
\text { places (2011) }\end{array}$ & 38.862 & 11.778 & 14.512 \\
\hline $\begin{array}{l}\text { Overall market } \\
\text { shares (2011) }\end{array}$ & $60,6 \%$ & $8,5 \%$ & $30,9 \%$ \\
\hline $\begin{array}{l}\text { Surgical market } \\
\text { shares (2011) }\end{array}$ & $45,8 \%$ & $8,6 \%$ & $45,5 \%$ \\
\hline Physicians' statuses & $\begin{array}{l}\text { Civil servants }^{3} \\
\text { Salaried (public) } \\
\text { employees } \\
\text { Casual workers }\end{array}$ & $\begin{array}{c}\text { Salaried (private) } \\
\text { employees }^{1}\end{array}$ & $\begin{array}{l}\text { Salaried (private) } \\
\text { employees and self- } \\
\text { employed }\end{array}$ \\
\hline $\begin{array}{l}\text { Number of } \\
\text { physicians (2011) }\end{array}$ & 94.877 & 16.838 & 41.843 \\
\hline
\end{tabular}

Sources: French National Health Accounts, 2013; DREES, Panorama des établissements de santé, 2013

See figure on Distribution of Health Facilities, 2012

Other charts in the supplements

The first efforts to coordinate the provision of care in France began in the 1970s. For nearly three decades after that, "health maps" were the main national instrument for Statecontrolled planning of hospital capacity and distribution of health facilities and equipment

\footnotetext{
3 Physicians who work as employees in public and non-profit sectors do have the right to work as private practitioners, so they can get a complement of income, which can be substantial. Those who work in university hospitals (Centres hospitalo-universitaires) can hold an academic status (e.g. professor of university) that also provides a significant additional income.
} 
throughout the country. Since 1977, public agencies have coordinated the healthcare offering in France. Today, the regional health agencies are tasked with adapting the national policies developed by the Ministry of Health to each region's specific characteristics. Accordingly, they coordinate public health strategies that combine preventive and care components through regional health programs. They draw up the "Schémas régionaux d'organisation des soins" (regional healthcare organisation plans) that replaced the "carte sanitaire" (national health maps) in 1991 as instruments for health planning. The regional agencies are supposed to ensure resources are managed coherently and to guarantee equal access to high-quality healthcare. Empowering regional health agencies represents a crucial shift in the French healthcare organisation. Though agencies enjoy a real degree of autonomy, their directors are appointed and managed at a distance by the Ministry of Health. Institutional coordination remains especially difficult because of the multiplicity of stakeholders, their concerns and the interests they defend. Coordination and continuity of care between private practitioners and public hospitals remain an endemic problem, as we shall see.

Nationally, health insurance and health policies' governance is equally complex. The diversity of compulsory and complementary plans complicates managing the social protection of health. The on-going backdrop of union elections prevents strong leadership in the joint organisations. In addition, negotiations among organisations that manage health insurance, doctors' unions and hospital's organisations often tend to degenerate, with the various stakeholders incapable of reaching an agreement ${ }^{11}$.

The mixed nature of the French system has turned out finally to be propitious, allowing diverse funding modes and medical practices to coexist. This diversity grants freedom to professionals and patients. But it also makes national regulation complex and fragmented.

\section{The State institutions' enhanced regulation capacities}

Over the past two decades, the French government has strengthened markedly its role in regulating the healthcare system. It exerts more direct control of various segments of the system which the professionals themselves had regulated with greater independence. Nonetheless, increased bureaucratic centralisation has not followed; the French system continues to be polycentric. This beefed-up control is paradoxical. Conducted under the cover of neo-managerial reforms lauding decentralised regulation, and autonomy of healthcare professionals and other stakeholders, it leverages tools borrowed from the private sector to govern and manage at a distance ${ }^{12}$.

The State's regulatory involvement is clear in the domain of health insurance, affecting a scheme that has granted a central role to social partners since 1945 . The central government first developed tools for regulating budgets, in particular by defining indicative 
budgets that foresaw restricted resource levels. In 1996, Parliament gained the power to define the budgetary rules and the ceiling of healthcare expenditure increases. It thus enacts the laws to fund the entire social insurance system. Parliamentary institutions' role thus expanded, as the increasing number of health-related bills show. France also elected to change how healthcare costs are funded. Besides the classic compulsory contributions levied on wages, the Contribution sociale géneralisée (or CSG, in which "généralisée" means revenues from "capital" also are taxed) is paid to the fiscal administration as a public insurance tax. Indeed, France, with the CSG, has departed from a traditional 'social insurance system', to go for a 'tax-based funding system' which relies on the State administration to collect the financial resources. This would probably be seen as a paradox for those in countries with tax-based systems that have politicians currently calling for social insurance models.

The French government has also defined the minimal insurance guarantees to be covered not only by compulsory insurance, but also by the chiefly private complementary plans. For historic reasons, such complementary guarantees were accorded automatically to residents of the three eastern districts Germany governed from 1870 to 1919 known as Alsace-Moselle. In 1999, universal basic health insurance offered the poorest populations other minimal guarantees. Finally, this year, a new set of minimal guarantees has been set for all salaried workers. Over these decades, the ability of public authorities to define health insurance coverage increased substantially.

The progressive reinforcement of the State's role in health insurance has led to changes in the governance of the social insurance system. While formally preserving the historic diarchy between the Ministry of Health and the health insurance administration, the 2004 statute instituted a different shared governance by uniting the group of compulsory funds (creation of the UNCAM - Union nationale des caisses d'assurance maladie), and the for-profit and non-for-profit complementary plans. The legislature has attributed unprecedented responsibility in this organisation to a government-appointed director. This person has uncommon formal powers and is sometimes considered a junior health minister. These powers include regulating health insurance financing and costs and organising and coordinating care, for example, of patients with diabetes (SOPHIA) or those being discharged from hospital (PRADO).

The State's enhanced role in organising care is also manifest in the new tools developed to regulate the hospital sector. The 1996-launch of regional hospital agencies and their later change into regional health agencies strengthened the central government's presence more than it carried out the administrative devolution of its prerogatives. The regional agencies, whose scope of responsibility was broadened in 2009 to include nonhospital care and social medicine, constitute an intermediate echelon between the Ministry of Health and local health professionals. Created under the guise of modernising public 
health policy, these agencies merged the regional and local offices of the Ministry of Health and the health insurance funds to improve regional coordination in providing care. Instead of respecting the principle of autonomy that guided the founding of these regulatory agencies, these reforms in fact helped the Ministry of Health regain control of the hospital sector. The increasing reliance on managerial tools and economic inducements is sometimes interpreted as a surreptitious form of liberalisation or privatisation of the healthcare system ${ }^{13}$. In fact, however, these new modes of health regulation benefit the ministerial bureaucracy most ${ }^{14}$, mainly by the continued convergence of the private hospital sector into the regulatory system applicable to public hospitals underway for several years. In 1991, the private sector was included in regional health planning and therefore in regional health resources programming. In 1997, it became subject to the same standards of assessment and certification as the public sector, under the supervision of a national technical agency. Since 2008, the same prepayment financing rules have been imposed on establishments in the public (for their medical, surgical and obstetric services only) and private sectors. More recently, both the public and private sectors have been engaged in the same quality assessment procedures, already envisioned as a supplementary funding mechanism ${ }^{15}$. In 2009 , hospital directors were made more clearly subordinate to the regional agencies. At the same time, however, their power within their hospitals was reinforced, to the detriment of the local decision-making bodies where, traditionally, medical professionals had played a primary role. The relations among the central government ministries, agencies and hospitals are in principle contractual, in an administrative concept guided by the new public management. In practice, however, they reinforce an hierarchical administration deeply rooted in French bureaucratic culture. The use of quality indicators exemplifies this trend. While such indicators were set up to empower patients and give them a chance to choose better hospitals, the national policy implemented turned out to be a rather formal and bureaucratic exercise, reinforcing the role of national and regional levels on hospitals.

\section{See Supplements - Panel on the idea of privatisation of health in France}

Less regulatory intervention by State agencies takes place in non-hospital care. The medical profession has succeeded until now in preserving its right to direct payment by patients, based on the procedures performed; the health insurance fund then reimburses the patient. This form of payment is traditionally considered a guarantee of the freedom for private doctors to practise and for patients to choose and bear economic responsibility. The doctors' unions have succeeded also in preserving the right to collective bargaining, granted in 1970 by the health insurance fund nationally, despite frequent conflict. These periodic negotiations determine the fees that doctors can charge their patients, who are then reimbursed by the health insurance fund ${ }^{16}$. This fund, now under more direct control from a State official, has developed ways recently of reducing healthcare professionals' autonomy. Doctors have had to agree to top up their fees, which depend solely on payment for performance, with a flat-rate payment the health insurance fund calculates according to 
various performance indicators. Many healthcare professionals, including pharmacists and nurses, are now paid directly by the fund for the reimbursable portion of the care via a thirdparty payer mechanism; the patient is no longer required to pre-pay and await reimbursement. Since the Touraine Law adopted on 14 April 2015 (see Panel 2), doctors must comply with this third-party payment scheme. These recent changes in how the health insurance fund pays for care have changed the direct relationship between healthcare professionals and patients-a key principle enshrined in the 1927 Charter of Private Medicine.

The 2015 'Touraine' law

The last French law on public health was adopted on 14 April 2015. Known as the 'Touraine's law (granted with the name of the Minister of Health), it focuses on health care access and prevention as top priorities of the national health agenda.

- The law extends health prevention actions in the areas of food, hygiene, sexuality and risk behaviors (smoking, alcohol), including through the development of school educational programs targeting young populations from kindergarten to high school. The law also facilitates access to emergency contraception without restrictions for young women.

- The law plans to disseminate the "third party payment" management system (système du 'tiers-payant') as a way to reduce financial barriers in access to health care, especially for the poorest populations. The third party payment allows patients not to advance medical expenses. After having been implemented in pharmacies in the last decade, it is planned to be extended to medical consultations: practitioners will be paid directly by the social security and supplementary health insurances.

- The law authorizes 'class actions' for medical disputes. Patients will be able to sue collectively companies when they are victims of accidents, especially those related to the use of medicinal products.

- The law also aims at expanding public access to health-related information. It establishes a "public service for health information" opened to citizens. It also plans to set a national health data system that will bring together major medical administrative databases (e.g. reimbursement of medical expenses, length of hospital stays, health facilities for people with disabilities, data on risks factors leading to premature death). It intends to open these data to NGOs and associations, health industries, complementary private insurance and research centers.

- The experimentation of 'shooting galleries' remains the most controversial measure. The law plans to experiment harm reduction programs through legalized drug use centers, over a period of six years. These centers will be used exclusively for particularly vulnerable drug addicts, under the supervision of health 
professionals, with the aim to reduce related infectious diseases (such as HIV and hepatitis) while reducing drug consumption through education.

Finally, State regulation of public health-long the 'poor relation' of the health authorities-has been reinforced ${ }^{17}$. The AIDS epidemic revealed these institutions' poverty and French public health policy's ineffectiveness. Subsequently, resources grew, stimulated by European programs and the need to respond to a series of health crises, such as bovine spongiform encephalopathy in $1996^{18}$. National (as well as European) technical agencies were created to strengthen health security and safety in pharmaceutical drugs, food and the environment ${ }^{19}$. At the same time, diverse agencies or independent authorities acquired jurisdiction in the regulation of healthcare; among them are the National Agency for Health Accreditation and Evaluation in 1997, replaced in 2004 by the High Authority for Health (HAS), and the National Agency for Drug Safety. Supposedly more reactive and more open to stakeholders than the traditional civil service administration, these French agencies have reproduced and even strengthened bureaucratic characteristics. The requirements of transparency to which they are subject promote the formalism of more numerous technical standards, while their organisations constitute a new hierarchical level within the administration. Moreover, these agencies' jurisdictions overlap and change constantly ${ }^{20}$.

\section{See supplements -Table on Distribution of jurisdictions among state administrations and} regulatory agencies, health insurance funds and local governments

Increased State regulation of the health sector is a result of several factors: the national and regional agencies network, the convergence of the public and private hospital systems, the expanded relationships between non-hospital and hospital medicine and the increase in State-regulated control of health insurance funds.

\section{Institutional polycentrism and coordination challenges}

The effects of the strengthened State role are not clear. In some respects, they take on paradoxical forms.

Firstly, this movement has not done away with the diversity of schemes and public and private operators within the French healthcare system. The general health insurance fund maintains a high level of coverage through the various compulsory schemes and the considerable financial participation of non-State operators (non-profit and private insurance) in healthcare funding. These complementary insurance plans apply especially to routine care, in particular the types compulsory health insurance reimburses poorly (e.g., orthodontics and ophthalmology), although they can represent a substantial expense for households. Some complementary insurance plans also offer limited coverage for alternative 
medicines (e.g., osteopathy and homeopathy). The restructuring underway has not modified fundamentally the balance between the public and private sectors in the healthcare supply. The latter has preserved a substantial market share of the hospital sector (especially for surgery) and private practitioners still provide the majority of primary care. Most ambulatory pharmacies and biological laboratories also are private.

The trend toward State integration is not necessarily producing better coordination between the funding institutions and the care providers. On the contrary, public decisionmakers, researchers and healthcare professionals agree that inadequate coordination in the healthcare system remains a key problem in current reforms ${ }^{21}$. For example, elderly or disabled individuals are often entitled to multiple sources of coverage that can be complex for the patients to manage $e^{22}$. Similarly, the absence of coordination between information systems linking the different non-profit complementary insurance providers to the compulsory system tends to impede rapid patient reimbursement. For health research, France does not have a body akin to the United States' National Institutes of Health to oversee public research funding. Many experts have underscored the dispersion of funding and programs among the Ministry of Health, the Ministry of Research, social protection bodies, national research organisations-including the National Institute for Health and Medical Research (INSERM), public health institutions (such as the Institut Pasteur) and still other public health agencies and institutes (such as the National Cancer Institute; the National Agency for Food Safety, the Environment and Labour; and the National Institute for Prevention and Health Education). In 2009, efforts to coordinate their activity led to creating a national research alliance in life sciences and health-the AVIESAN alliance, which INSERM chairs. Beyond its mandate to spearhead research, the alliance is engaged in coordinating health research programs to an extent unprecedented in France. By its scale and its intentions, this process can be compared to the UK National Health Service's research and development program, developed from 1994 onward under the supervision of Michael Peckham and which led to NIHR's founding in 2006.

The inadequacy of institutional coordination is more flagrant still in the provision of care. The successive reforms have introduced new coordination, often tacked on to previous systems and compounding organisational complexity. Moreover, although some recent analyses estimate that coverage has improved, geographic disparities persist, such as between metropolitan and overseas territories ${ }^{23}$, and with them inequalities in access to care and prevention. The freedom of private practitioners to choose where they practise has not been called into question, despite attempts at reform involving doctors' unions, doctors and medical students. Today, this policy of geographic balance in the availability of primary care is being implemented with extreme caution. It involves slow readjustments in the number of students admitted to different medical schools each year and (totally ineffective) financial incentives to set up practice in areas considered medical deserts ${ }^{24}$. Looking forward, medical deserts are an increasing concern in some areas, especially in rural 
departments. Coercive measures to spur the installation of physicians in such areas are viewed as inadequate. Public authorities have supported creating around 800 crossdisciplinary "maisons de santé" (medical health centres) to provide care, both in urban and in more deprived rural areas.

\section{See figure - Geographical density of general practitioners for}

Enhancing the role of primary care has been a major theme of recent reforms, through creating care networks and nursing homes and experimenting with different pay schemes for doctors (e.g., as employees or with bonuses associated with public health projects). This deals simultaneously with issues of geographic access to care, coordination among healthcare professionals and support for public health activities (prevention, screening, etc.). Evaluations are underway, but some have argued already that attempts to include more general practitioners in care networks have thus far met only limited success $^{2526}$.

Yet another prominent aspect of lack of coordination involves information systems linking care providers. In 2004, a law was passed to promote the digitalisation and centralisation of each patient's medical records to facilitate information exchange. This program has faced multiple delays, and the integration of information systems between healthcare professionals and hospitals remains minimal. Finally, despite recent regulatory attempts intended to streamline the healthcare pathway, the care actually provided remains largely the product of an informal work organisation driven by professional logic.

Finally, the coherence of prevention policies and health education is still limited. Despite the reaffirmation of the State's role in recent years ${ }^{27}$, non-profit associations and private operators are part of the many players in this domain. Henceforth, in key areas (e.g. alcohol and tobacco consumption, obesity), the primary goal of prevention policies has been to influence individual behaviour rather than target structural causes. Current health prevention measures put the onus on individuals to reduce at-risk practices by changing their habits and lifestyle ${ }^{28}$. They emphasize individual responsibility and autonomy, as patients are provided with information and health education, and continue to benefit from the broad coverage for their health expenses

As we have seen, the French healthcare system has undergone gradual transformation in recent decades leading to a reinforced State role in oversight and evaluation and a loss of power for social partners in governing the health insurance system. Medical professionals and patients still benefit from autonomy and freedom of choice. This dichotomy party explains extant coordination challenges; yet, the health insurance system continues to fulfil the redistributive goal founders assigned to it in 1945. 


\section{Health coverage in France: Redistributive effects and social determinants}

Countries such as France that have chosen universal health coverage face two major economic questions: a macroeconomic one-how much does universal access cost? And a microeconomic one - what is the net result of health insurance on family budgets? In other words, what is the cost-benefit balance of health insurance per individual or per household living in France and insured? The question of health insurance in France has always been linked to discussions about its redistributive nature. It also raises the issue of social inequalities in health. In its principles of access to care as in its funding methods, the French system aims to promote equality of access among citizens. But the facts show that social inequalities in health outcomes continue and appear to be getting worse, especially for specific diseases such as obesity and cancer $^{29}$. Is this a sign the French system is failing to reach its egalitarian objectives? Or a sign that policy that has not succeeded in fully measuring the myriad causes of social inequalities in health, which take place well before the healthcare system comes into play?

\section{Macroeconomics: Socialised funding of healthcare costs}

France is one of the countries with the highest healthcare outlays. In 2012, with annual per capita expenditures of $€ 3,650$ (US $\$ 4,288$ ), France ranked third among the large OECD countries for healthcare costs as a proportion of GDP (11.6\%), trailing only the United States (16.9\%) and the Netherlands (11.8\%). Nonetheless, this percentage is close to those of other European countries (Germany, 11.3\%; Belgium, 10.9\%) or OECD members (Canada, 10.9\%). Similarly, when we look at the proportion of total healthcare costs represented by public expenditure, France is indistinguishable from other countries (again, except the United States): in 2012, public spending for healthcare represented $77.4 \%$ in France, $76.8 \%$ in Germany, $75.2 \%$ in Belgium, $70.1 \%$ in Canada and $85.8 \%$ in the Netherlands. These figures contrast sharply with the percentage in the US, which was only $47.6 \%$ in 2012 . This difference testifies to the fundamental differences in ways of funding healthcare. In France, private insurance companies or non-profits (mutuelles) supplement compulsory health insurance coverage funded by public contributions. 


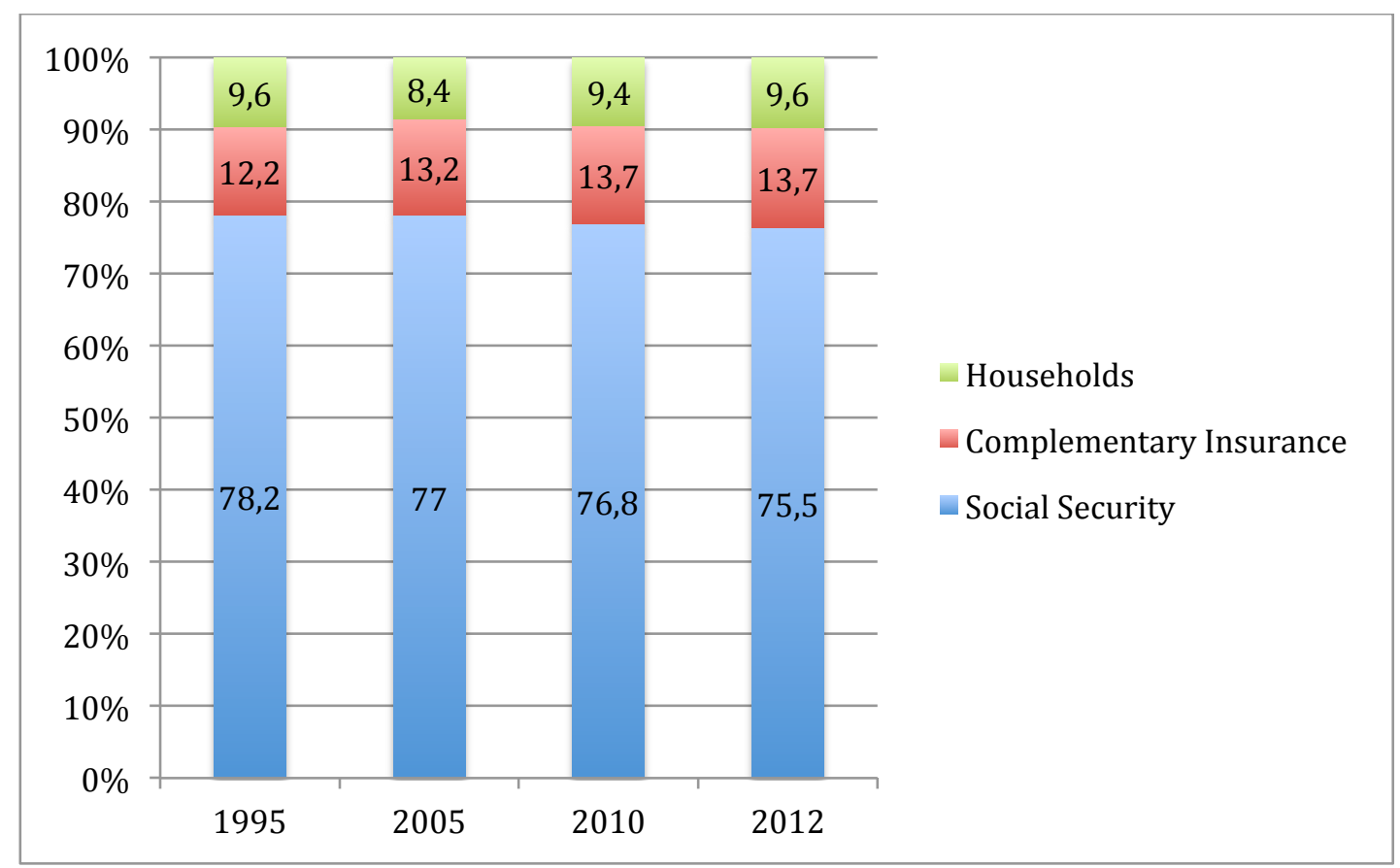

Source : France National Health Accounts, 2013

In that light, health costs appear to be well covered in France: $92 \%$ of these costs were reimbursed to French patients (compared with $87 \%$ in Germany, $79.6 \%$ in Belgium, $85 \%$ in Canada and $88 \%$ in the USA). Only the Netherlands had slightly higher coverage at $94 \%$. These findings show the French system is one of the most comprehensive, with only $8 \%$ of out-of-pocket spending. Nonetheless, the overall rate of $92 \%$ and, within this figure, the relative proportions of compulsory public insurance and private insurance vary according to the person and the disease. Generally, public health insurance provides $100 \%$ coverage for expensive chronic diseases, which mainly affect the elderly (e.g., diabetes, cancer, or cardiovascular diseases). The private sector, on the other hand, covers costs associated with auxiliary services, considered as low risk (such as dental, optical, and minor disease expenses). Because it specialises in major diseases and exempts patients from co-payments for them, public insurance funds' overall reimbursement rate has remained stable for the past decade, even though it has tended to reduce specific rates for some types of care (for example, drugs with poor therapeutic efficacy). Population ageing leads to an increasing proportion of people benefitting from $100 \%$ coverage for chronic diseases, thus maintaining the volume of public health spending.

Year after year, governments face a public insurance deficit ( $€ 17$ billion in 2012 , or $0.8 \%$ of GDP). Healthcare costs are growing at a faster rate than the French GDP, which is the tax base for the revenue allocated to financing the social insurance funds. In fact, the deficit 
results mainly from France's weak economic growth. Recent work has shown the health insurance accounts would have been balanced since the beginning of the century had GDP grown by an annual rate of 2 to $3 \%^{30}$. It is thus the low growth of the $2000-2010$ decade that has required the State to shoulder this deficit.

\section{Microeconomics: A redistributive funding system}

Coverage of healthcare costs and its funding vary considerably by income level. When we divide the French population by income deciles (figure 4), we see a clear trend in the distribution among public insurance, complementary insurance and out-of-pocket spending for households. The poorest groups benefit fully from the different public coverage schemes (for households in the lowest decile of the population, the compulsory system and the free complementary plan cover nearly $90 \%$ of the costs of care). Inversely, the more well-to-do use more of the types of care the public funds do not cover as well. For them, the public fund covers on average less than $70 \%$ of their costs. This difference between the rich and poor does not result solely from the qualitatively different healthcare consumption of the wealthier segments of the population. We know the two or three low income deciles concentrate a high proportion of elderly people, who have retired, have modest pensions and often, because of their age, suffer from long-term chronic diseases that exonerate them from co-payments (this is particularly true for the D2 decile where graph 6 shows a peak in healthcare consumption). This automatically triggers a high reimbursement rate.

Analysis of contributions to the health insurance system also reveals substantial variations according to income.

\section{See Figure - Contributions and benefits of households in the ten income-deciles}

These two graphs plot the contributions and the benefits from the health-insurances system of the French residents grouped per income-deciles (D1 the poorest; D10 the richest). The horizontal line is the national average (D1 to D10, sum of the average contributions to the two types of insurances, $=5190$ euros in 2008). The left-hand side part is clearly progressive, due mainly to the progressivity of the National Health Insurance taxation policy. The benefits (right-hand side) are flatter, meaning that the reimbursements concern almost equally the respective social segments of the French Society. The main mechanism of redistribution is coming from this dissymmetry between contributions and reimbursements.

Analysed by income decile, the data show the clear progressiveness of payroll taxes that finance the public health insurance system. The private system is almost flat as the rates it charges are rarely based on household income (A). These data should be compared with the level of reimbursement paid by the public health insurance fund, which remains globally flat along the income axis (B). This comparison of payments to and reimbursements from the public system highlights the important redistributive effect from the well-to-do toward the poor of the French health insurance system. It is more redistributive than schemes where contributions are determined only on the basis of a lower risk of disease. To understand this 
transfer, socioeconomic and epidemiological factors must be examined together. As the poor are sick more often, a natural redistributive effect occurs that is favourable to themthe direct effect of the "horizontal redistribution" between the healthy and the ill intrinsic to all health insurance systems. But more detailed analyses show that the redistributive character of the system persists when this poor/rich epidemiologic effect is removed ${ }^{31}$. To use the terminology of economists specialising in inequalities, there is "vertical redistribution", even after adjustment for the horizontal redistribution (from the healthy to the sick) that intervenes automatically with the consideration of the socioeconomic gradient in health risk.

This redistributive effect is an important dimension of the health insurance system in France. It is much stronger than in education, for example, where the social balance between contribution levels and program benefits remains low, as the poorest families use fewer public education services ${ }^{32}$. International comparisons show the French health insurance system is one of the three most redistributive systems among OECD countries, especially due to the stronger progressiveness of its contribution levels than in other countries ${ }^{33}$. The creation in $\mathbf{2 0 0 0}$ of a specific system of access to care for the poorest people in France-the $\mathrm{CMU}$-has accentuated further this redistribution process. For the poorest populations, the $\mathrm{CMU}$ represents a shift from employment-based coverage to one based on residence. The most disadvantaged groups now have access at the same time to public insurance (with no conditions other than residence) and free complementary health insurance.

Overall, the combination of public insurance and private insurance-which is not redistributive but completes the services abandoned by the public system-makes it possible to "fit" the real price paid by each to the "ability to pay" of each. More precisely, out-of-pocket spending for healthcare ranges from $4 \%$ for households in D1, D2 and D3, to $13 \%$ for the richest decile (D10).

The French system nonetheless has deficiencies. Over $20 \%$ of members of population categories entitled to the free complementary universal system do not use it ("non-take-up" phenomenon). Moreover, this system, which is based on a poverty criterion, displaces the problem toward the less poor, but still very low-income categories, for which this complementary insurance is not free ${ }^{34}$. Some types of care are not included in the basket of reimbursed expenses (including preventive care, some vaccines and preventive dental care); this leaves substantial out-of-pocket charges that are obstacles to access to care. Finally, observing redistributive transfers promoting access to care for the most in need at any given moment provides no information on situations they may face throughout their lives. The premature mortality of the poorest (see latter, Figure S2 - Supplements) may mean that the system, redistributive in a cross-sectional view, is much less so over an entire life cycle: if people in the different income groups do not have the same life span, their ability to capture redistributive transfers is not in fact the same in an inter-temporal perspective. 


\section{Social inequalities in health: French paradox or universal phenomenon?}

The French system of funding theoretically should create the best conditions for equitable access to health, through its dual mechanism of vertical (favourable to the poorest) and horizontal (favourable to the populations most vulnerable to the risk of disease) redistribution. Nonetheless, a qualitative observation of healthcare use shows important differences among social groups, after adjustment for their health needs (age, gender). The principle of horizontal equity requires that each person should receive care according to his or her health needs. Many empirical studies show that healthcare utilisation behaviours differ by social group ${ }^{35}$.

These differences in healthcare use among social groups have been documented clearly in France. Analyses measuring the odds ratios associated with different income levels show that after controlling for age, gender and health status, significant differences exist among social groups for specialist care: the most well-off half of the population sees specialists twice as often as the poorest $25 \%{ }^{36}$. Similar reports abound for preventive care-especially screening programs, even though some of them are free (e.g., colonoscopy, mammography, eye examinations). Moreover, social health inequalities may increase along with medical innovations because the richest part of the population more quickly benefits from the latest techniques ${ }^{37}$.

Nonetheless, international comparisons show that social inequalities in access to care are a nearly universal phenomenon. Among comparable countries, France is located at the median of OECD countries ${ }^{38}$. A comparative analysis of healthcare systems shows that both the organisation of care and the principles applied for funding the healthcare system are important factors that affect the inequalities in healthcare use. "National" (or universal) health systems succeed better at reducing differences in access to care than employmentbased systems, partly because that care is free and because general practitioners, as referring physicians, filter access to care. From this perspective, the changes made to the French system's organisation to reinforce the role of primary care and screening access to the system, through the institutionalisation of general practitioners as referring physicians for the patients, will help reduce these inequalities ${ }^{39}$.

Social inequalities in health outcomes remain important, as several key figures underscore: at age 35 , the life expectancy of a male manual worker is 6.3 years less than that of a senior executive ( 3 years less for women); men who have no secondary school diploma are 2.5 times more likely to die before the age of 65 than men who attended higher education institutions (1.9 for women). These figures are available in graph 7 for 2008. Of note, should we consider the same figures for 2003, the gap between manual workers and executives would be a bit narrower (5.7 points instead of 6.3), suggesting an increase-or at least a perpetuation-of social inequalities in death rates. Some morbidity variables also show a 
social gradient: the frequency of depressive episodes is $9 \%$ in the general population, compared with $16 \%$ among the unemployed and those not in the labour force ${ }^{40}$. For cancer, the most studied disease in relation to social disparities in health, large inequalities have been observed among men, especially for upper aero-digestive tract cancer (UADT). Such inequalities increased between 1968 and 1981 among men and remained stable thereafter. Social inequalities were less pronounced among women, but were still observed for lung, uterine and stomach cancers ${ }^{41}$.

Social inequalities in health outcomes have been analysed widely ${ }^{42}$. In France, as in other countries, social factors play a role well before considerations of access to the healthcare system come into play. Each social position corresponds to a particular combination of resources and risk factors. The determinants of health inequalities can be classified in several categories: biological determinants, which are in principle independent of the social situation although recent work has shown links between epigenetic markers and embryonic and foetal life ${ }^{43}$; behavioural determinants (e.g., smoking, alcohol, diet, physical activity), themselves influenced by social and occupational positions; environmental determinants associated with living (e.g., habitat) or working conditions (e.g., drudgery, exposure to pollutants $)^{44}$; and socioeconomic conditions of society as a whole (e.g., social stratification, income, training and work). The most disadvantaged social categories accumulate all of these risk factors. Even psychosocial risks and stress at work affect the lowest occupational and social categories more frequently or more strongly ${ }^{45}$.

See Article and Supplements: Figures on social inequalities in health in France

Health inequalities by ethnic group or race are studied rarely in France since gathering ethnic and racial statistics is forbidden. Recent work, however, shows that the health of immigrants is generally less good than that of the native-born French population: a foreign immigrant is at higher risk of reporting poor health than a French person born in France (crude odds ratio= 1.5); for comparable age and gender, this risk is higher still (odds ratio $=1.74)^{46}$. The economic and social conditions of immigrants in France partly explain these inequalities. But, beyond that, analysis of differences according to country of origin appears to show that the level of development of the country of origin also has a long-term effect on immigrants' health.

The influx of migrants fleeing war is another challenge French and European health systems have to face. In some cities (Paris and Calais, for example), hospitals' health service access points for those living in precarious conditions (PASS or Permanences d'accès aux soins de santé pour les personnes précaires) are overwhelmed and cannot respond adequately to migrants' needs. Though the epidemic risk of tropical and infectious diseases is low, those related to precarious living conditions (gastro-enteritis, tuberculosis) cannot be ignored.

Existing studies on health in France do not compare the health status of homeless people to 
the rest of the population. However, some surveys focusing on disadvantaged groups show that homelessness is a factor that may worsen health conditions. For instance, among beneficiaries of temporary accommodations or hot meal distribution, $16 \%$ of homeless people declare poor or very poor health v. $3 \%$ of people with stable accommodations. Differences in rates are significant for all diseases, but they are especially high for migraines, respiratory diseases, accidents or diet-related diseases. These surveys illustrate the longer one is homeless, the worse one's health becomes. Finally, infectious diseases such as tuberculosis are starting to reappear in such populations. Tuberculosis is more prevalent in homeless populations $(120$ cases per 100,000$)$ than in those with stable housing $(4.3$ cases per 100,000).

See Supplements: Figures on Health status of the homeless in France

\section{Addressing the root causes of social inequalities in health}

Social inequalities in health depend principally on the circumstances in which individuals are born, grow up, live, work and age ${ }^{47}$. In turn, health conditions can affect individuals' social situation, especially when chronic disease affects their work ${ }^{48}$. Redistribution mechanisms cannot compensate for the cumulative effects of these major social factors that act ahead of and independently from the healthcare system ${ }^{49}$. Since the social insurance system began, French policy has focused on addressing financial barriers to health and has succeeded at achieving formal equality in access to healthcare. There have been some marked successes in controlling risk behaviours linked with social determinants. For example, mortality from alcoholic diseases has fallen markedly, with 13,500 fewer deaths in 2012 compared to 1982 (CePiDc-INSERM). France has also taken a very strong line on smoking that will have an effect on mortality from tobacco-related diseases in the next ten years. More recently, it has implemented policies aimed at attacking the root causes of social inequalities in health outcomes. The Public Health Act of 2004 was a first turning point. In 2009, launching its second Cancer Plan, France placed inequalities at the heart of its public health policy. The new President of the Republic reaffirmed this priority in 2012 (Third Cancer Plan, Touraine Law $)^{50}$. Implementation is far from simple. Directing prevention policies toward vulnerable populations can be counter-productive: if they contribute to stigmatising these populations, they risk increasing inequalities still further, as shown by studies of public action against smoking and obesity ${ }^{51}$.

Equality of access to care through vertical and horizontal redistribution strives to enable the social insurance system to correct what it can. The social solidarity the French system instituted has had a positive effect on living conditions in general and on health. Compared to the British healthcare system, the French system is far from reaching its target of reducing those inequalities attributable to inherited social circumstances on which the system can 
act $^{52}$. However, this objective should not be abandoned: it remains a necessary, albeit insufficient, condition for reducing inequalities ${ }^{53}$. Better equality in access to healthcare has a positive impact on the quality of life of the most poor ${ }^{54}$. Reducing social inequalities in health may well make society as a whole stronger ${ }^{55}$.

\section{Challenges in the next decade}

The French healthcare system will confront various challenges in its governance in the next ten years and most importantly reorganising a system built after World War II on one central pillar, the public hospital, which involved physicians in regulating the healthcare system. The increasing prevalence of chronic diseases among an ageing population calls for a new transversal scheme articulating hospital services with ambulatory and social care. This shift must be tackled in a context of stricter budget restrictions and costly medical advances. The founding values of the French healthcare system, which find strong popular support, are under pressure: today, combining excellence in health services and social equality in health appears necessary but hardly sustainable. This tense equation requires new forms of governance that coordinate a wide range of actors, interests and stakeholders at different levels nationally and regionally. Beyond economic and medical issues, France thus has to face a new democratic challenge. Parliament's increasing role and new forms of participation of patients and citizen's organisations prove that a more inclusive healthcare system must replace gradually the sector's traditional regulation. To date, professional associations representing the various medical occupations have had a major influence in negotiating successive health reforms. This shift could make reorganising the healthcare sector easier over the years, despite political and economic pressure.

Beyond the issue of coordination, the French healthcare system risks evolving into a sociallyfragmenting "two-tier system". Increasing socioeconomic inequalities combined with efforts by health professionals to flee the public system's harsh budgetary constraints may reinforce gradually a "high quality - high price - no waiting - private healthcare sector". Growth in the number of protest movements, grounded in 1992 European legislation abolishing France's social security monopoly and that seek to avoid social security contributions, could reinforce this trend. Economic globalisation, moreover, permits the wealthiest segments of society to off-shore their income and thus escape French solidarity contributions. That an increasing share of ambulatory-care physicians - and sometimes hospital physicians working for public institutions -charge above regulated fees indicates that the risk of fragmentation is real. The government response has been to officialise these practices and to render conditional and set limits to these fee surcharges (the surcharge must remain below $150 \%$ of the regulated fee). It may not be sufficient to reverse the trend in the departure of the wealthy, a challenge most European countries face. In France, such a social split is already a reality in some public services, notably the school system. The fight against fragmentation in the 
healthcare system is the battle France must not lose.

Meanwhile, that the most disadvantaged and the lower middle class are tending to renounce healthcare remains an important challenge to universal access to health in the next decade. The Touraine Law (see box 2) plans to generalise the "third-party payment scheme" for private medical consultations, thereby extending a system already in place for the delivery of prescriptions. Reducing health disparities in the population, however, cannot be met only through financial incentives as social health inequalities result from social and professional factors distinct from the healthcare system. The fight against the health divide requires public health policies that fully integrate such factors. Tomorrow, the wealthiest will have easy access to "high-tech", personalized and even predictive medical care thanks to advances in genomics. For the most disadvantaged groups-and to a large extent for the middle class-health policies will have to act on behavioural, environmental and professional risk factors, and to set up ambitious health education and prevention programs. The subsequent challenge will be to make high-tech medicine accessible to all.

\section{Conclusion}

Four main lessons can be drawn from the evolution of the French healthcare system in the last decades. Firstly, health insurance coverage remains broad and redistributive in France in comparison to other OECD countries. It plays an important role in social cohesion. More broadly, access to basic healthcare is recognised as a fundamental human right: good health is an essential element of freedom. Health has been considered for a century a public good for which the government is responsible.

Secondly, State administrations and agencies have become gradually the leading players in regulating health insurance and healthcare provision. Key institutional features of the French system, such as the traditional dualistic balance between employment and government institutions and the territorial autonomy of public and private healthcare providers, are increasingly less prominent. Ironically, at this time, both patients and doctors maintain particularly high levels of autonomy.

Thirdly, institutional fragmentation and lack of coordination remain serious policy challenges for effective healthcare services. For reformers, these challenges justified stricter accountability and surveillance mechanisms through State public agencies and geographic and budgetary planning. At the same time, the development of quasi-market regulatory tools has made it possible to apply more widely the principles of result-based management and the use of incentive mechanisms (such as payments for performance, remuneration for public health objectives and activity-based financing).

Finally, redistribution does not have only a social or moral aim: it also improves health 
nationally. Nonetheless, in France, as in most high-income countries, the redistributive system still does not provide an effective response to social inequalities in health. It befalls the State to develop more effective policies targeting the causes of these inequalities. Public policies must target areas outside the healthcare system to combat these inequalities. France has started to shift toward such policies, as shown by health-related laws enacted since 2004. Nonetheless, the austerity policies successive governments have applied in France in the continuing aftermath of the deep economic and financial recession of the late 2000s has slowed progress toward these objectives. The French State is not disengaging from the healthcare system: its financial commitment continues. Economic policies, however, to boost labour market flexibility and reduce social expenses have a harmful effect on unemployment and poverty, both important health determinants. Developing a sustainable system that allows for effective policies to redress health inequalities is going to depend in large part on political choices. 


\section{HIGHLIGHTS}

- The French health system promotes the principle of healthcare insurance based on a redistributive funding model. It includes, in particular, a specific system of free access to care for the very poor.

- The French healthcare system features a high level of institutional diversity: a centralised public regulatory authority, coexisting with a public/non-profit/private mix of health insurance providers and of hospitals, together with a large sector of self-employed physicians for the provision of primary care.

- This institutional mix guarantees nearly universal coverage of the French population and sharply reduces financial barriers to access for the poor-all at a reasonable total cost (11.6\% of the GDP).

- This institutional heterogeneity allows both healthcare professionals and patients a high degree of freedom. It also increases the complexity of the regulation mechanisms for both social security and healthcare provision.

- Over the last two decades, government institutions have strengthened substantially their role regulating the healthcare system, through the development of oversight and monitoring mechanisms in three domains: the governance of health insurance, the organisation of healthcare provision, and public health

- In such a hybrid system, coordination among multiple health providers and decisionmakers can be difficult and may lead to waste of resources. Improved coordination is required in the areas of health insurance funding, information sharing (among healthcare providers), health research, healthcare delivery services, prevention policies and health education programs.

- The French healthcare system is one of the most redistributive among OECD countries, especially because of the strongly progressive nature of payroll taxes. It combines horizontal redistribution (for those most exposed to health problems) with elements of vertical redistribution (for the poorest) through the automatic application of sliding scales based on income.

- In the domain of health insurance, numerous private complementary plans augment the compulsory system and play a key role today in funding the primary care associated with minor risks.

- As in many high-income countries, health inequalities depend especially on socioeconomic determinants (e.g., social category, access to employment, income and educational level). These determinants are added to the behavioural and environmental risk factors that affect the most disadvantaged.

- The goal of reducing social inequalities in health has not yet been met. Although the most recent statutes focus more directly on non-monetary sources of health inequalities, some socioeconomic determinants maintain unequal access to some categories of care (specialists, dentistry, eye care and glasses). The mechanisms of redistribution cannot compensate for the cumulative effects of these major social factors that act ahead and independently of the healthcare system.

- Since the very origin of the social insurance system, French policy has relied strongly on dealing with financial barriers. It has recently implemented policies aimed at addressing the root causes of social inequalities in health. 
Conflict of interest statement: Professors Nay, Béjean, Benamouzig, Bergeron, Castel and Ventelou have nothing to disclose.

Author contributions statement: Professors Nay, Béjean, Benamouzig, Bergeron, Castel and Ventelou have contributed jointly to the whole paper. All authors have seen and approved the final text.

Acknowledgments: This paper received funding from the French National Research Agency (ANR) under the "Investissements d'avenir" program with reference ANR-11-LABX-0021-01-LipSTIC Labex, the region of Burgundy through the PARI funding program.

\section{References :}

${ }^{1}$ Atlani-Duault et al., State humanitarian verticalism versus universal health coverage. One hundred years of French international health assistance revisited, The Lancet (in this special issue), 2016

2 Benamouzig D, Besançon J, Administrer un monde incertain : les nouvelles bureaucraties techniques, Sociologie du travail, 2005, 47(3): 301-322 ;

${ }^{3}$ Nathanson C, Disease Prevention as Social Change, 2007 Sage

${ }^{4}$ Berlivet L, Une santé à risques. L'action publique contre l'alcoolisme et le tabagisme en France, Unpublished PhD manuscript, Université de Rennes, 2000

5 Etilé $\mathrm{F}$, Obésité. Santé publique et populisme alimentaire, 2013 Editions rue d'Ulm

6 Palier B, Gouverner la sécurité sociale, 2005 Puf

7 Immergut EM, Health politics: Interests and Institutions in Western Europe, 1992 Cambridge University Press; Palier, ibid., 2005

8 Jamous $\mathrm{H}$, Sociologie de la décision. La réforme des études médicales et des structures hospitalières, 1969 Editions du CNRS ; Hassenteufel P, Les médecins face à l'Etat, 1997 Presses de Sciences Po

9 Esping-Andersen G, The Three Worlds of Welfare Capitalism, 1990 Princeton University Press

${ }_{10}$ Chevreul K, Durand-Zaleski I, Bahrami S, Hernández-Quevedo C and Mladovsky P., France: Health System Review. Health Systems in Transition, 2010, 12(6): 1-291.

11 Hassenteufel, 1997, op. cit. ; Palier, 2005, op. cit.

12 Benamouzig D, Pierru F, Professionals and the "System": the institutional integration of the medical world, Sociologie du travail, 2012, 54(S1): e32-e38

13 Belorgey N, L'hôpital sous pression. Enquête sur le nouveau management public, 2010 La Découverte

${ }^{14}$ Benamouzig D, Du grand soir au clair-obscur. Expertise économique et privatisation bureaucratique de I'assurance maladie, Actes de la recherche en sciences sociales, 2012, (193):56-73

15 Benamouzig $D$, Robelet $M$, Les indicateurs qualité et l'intégration bureaucratique de l'hôpital, Quaderni, 2014, 85: 68-85

16 Hassenteufel P, Davesne A, Les médecins face aux réformes de soins. Une mise en perspective comparative France - Allemagne - Suède, 2013 Etude pour l'Institut Montparnasse

17 Morelle A, La défaite de la santé publique, 1995 Flammarion; Bergeron $\mathrm{H}$, Les politiques de santé publique, in Borraz O, Guiraudon V (eds), Politiques publiques. 2, changer la société, 2010 Presses de Sciences Po, 79-111

18 Guigner S, L'institutionnalisation d'un espace européen de la santé, 2008 Université de Rennes

19 Tabuteau D, La sécurité sanitaire, 2002 Berger-Levrault

20 Benamouzig D, Besançon J, Administrer un monde incertain : les nouvelles bureaucraties techniques,

Sociologie du travail, 2005, 47(3): 301-322 
${ }^{21}$ Saliba B, Ventelou B, Complementary health insurance in France Who pays? Why? Who will suffer from public disengagement?, Health Policy, 2007, 81(2-3): 166-182

22 Bloch MA, Hénaut L, Coordination et parcours. La dynamique du monde sanitaire, social et médicosocial, Paris : Dunod, 2014

${ }^{23}$ Chevreul et al., 2015

24 Déplaude MO, De l'erreur en politique. Le cas de la régulation démographique du corps medical en France (1980-2005), in Chauviré C et al., Dynamiques de l'erreur, 2009 EHESS, 335-361

25 Mathieu-Fritz A, Esterle L, Les transformations des pratiques professionnelles lors des téléconsultations médicales. Coopération interprofessionnelle et délégation des tâches, Revue française de sociologie, 2013, 54(2): 303-329

${ }^{26}$ Robelet $M$, Serré $M$, Bourgueil Y, La coordination dans les réseaux de santé : entre logiques gestionnaires et dynamiques professionnelles, Revue française des affaires sociales, 2005, 1: 233-260 27 Bergeron $\mathrm{H}$, Nathanson C, Construction of a policy arena: The case of public health in France, Journal of Health, Politics, Policy, and Law, 2012, 37(1): 5-36

28 Bergeron $\mathrm{H}$, Castel $\mathrm{P}$, Nouguez E, A public policy designed and run by a private entrepreneur. Tensions between public health and private interest in the battle against obesity in France, Revue française de science politique (English version), 2011, 61(2): 19-46

29 Leclerc A, Chastang JF, Menvielle G, Luce D, Socioeconomic inequalities in Premature Mortality in France : Have they windened in recent decades ? Soc Sci Med $2006 ; 62 ; 2035-45$

30 Cornilleau, G, Le financement de l'assurance maladie en question. Les Tribunes de la santé, 2009, 4: 7177

31 Duval J., Lardellier R., La redistribution verticale opérée par l'assurance maladie, Études et résultats, $n^{\circ} 815$, Drees, octobre 2012

32 Angels B., Retour sur l'économie des dépenses publiques, Rapport d'information 441, Délégation du Sénat pour la planification, 2008

33 Wagstaff, A., Van Doorslaer, E., van der Burg, H., Calonge, S., Christiansen, T., Citoni, G., ... \& Winkelhake, $O$. Redistributive effect, progressivity and differential tax treatment: Personal income taxes in twelve OECD countries. Journal of Public Economics, 1999, 72(1): 73-98

34 Delvallée, C., Ventelou, B. Assurance maladie: Redéfinir le partage entre couverture obligatoire et complémentaire?. Revue de l'OFCE, 2004, 4, 333-348

35 Jusot F, Or Z, Sirven N, Variations in preventive care utilisation in Europe, Eur J Ageing 2012, 9(1), 15-25 36 Or Z, Jusot F, Ylmaz E, The European Union Working Group on Socioeconomic Inequalities in Health, Inégalités sociales de recours aux soins en Europe : quel rôle pour le système de soins, Revue Economique, 2009, 60(2):521-43

37 Deaton A. (2002), "Policy Implication of The Gradient of Health and Wealth", Health Affairs, 21, 2 : 1330

38 Devaux $M$, de Looper $M$, Income-related inequalities in health services utilisation in 19 OECD countries, 2008-2009, OECD health working paper $n^{\circ} 58$, OECD publishing 2012

${ }^{39}$ Bourgueil $Y$, Jusot $F$, Leleu $H$, and AIR Project, Comment les soins primaires peuvent-ils contribuer à réduire les inégalités de santé, Questions d'économie de la santé, Institut de recherche et de documentation en économie de la santé (IRDES), 2012, 2(179)

40 Leclerc $\mathrm{A}$, Kaminski $\mathrm{M}$, Lang $\mathrm{T}$, Inégaux face à la santé : du constat à l'action, Institut National de la Santé et de la Recherche Médicale, 2008 Ed La Découverte, 300

${ }^{41}$ Menvielle, G., Leclerc, A., Chastang, J. F., \& Luce, D. (2008). Inégalités sociales de mortalité par cancer en France: état des lieux et évolution temporelle. InVS, BEH, 33, 289-292

42 Marmot SM. Closing the health gap in a generation: the work of the Commission on Social Determinants of Health and its recommendations. Global Health Promot 2009; 16(1):S23-7

43 Rooij SR de, Wouters H, Yonker JH, Painter RC, Roseboom TJ, From the cover : prenatal undernutrition and cognitive function in late adulthood, Proceedings of the National Academy of Sciences (PNAS) 2010,107(39): :16881-6

${ }^{44}$ Serrier H, Sultan-Taïeb H, Luce D, Béjean S (2013) "Estimating the social cost of respiratory cancer cases attributable to occupational exposures in France", Eur J Health Econ, 15(6), S661-673 
${ }^{45}$ Sauze $D$, Sultan-Taïeb $H$, Vieillard B, L'évolution récente de l'exposition aux risques psychosociaux en Europe, in Dedessus-Le-Moustier N, Douguet F, La santé au travail à l'épreuve des nouveaux risques, Ed Lavoisier, 2010, 95-106; Béjean and Sultan-Taieb, 2005; Béjean S, Sultan-Taieb H, Modelling the Social Cost of Diseases Imputable to Stress at Work, Eur J Health Econ, 2005, 50(1):16-23

46 Dourgnon $P$, Jusot $F$, Sermet $C$, Silva J, La santé perçue des immigrés en France. Une exploitation de I'Enquête décennale santé 2002-2003, Questions d'économie de la santé, Institut de recherche et de documentation en économie de la santé (IRDES), 2008, (133)

47 Marmot M, Bell R, Goldblatt P. Action on the social determinants of health. Revue d'Epidémiologie et de Santé Publique, Epidemiology and Public Health, 2013; 61(supplement 3) ; 2013, S127-S132

${ }^{48}$ Saliba B, Paraponaris A, Ventelou B "Obesity and Employability, Empirical evidences from a French national survey", Economics and Human Biology, 2005, 3: 241-58; Dray-Spira R, Maladies chroniques et emploi : impact en termes d'inégalités sociales de santé, Revue d'Epidémiologie et de Santé Publique, Epidemiology and Public Health, 61 (supplement 3); august 2013, S146-S151

49 Moatti JP, Déterminants sociaux des inégalités de santé : une priorité absolue pour la recherche en santé publique, Revue d'Epidémiologie et de Santé Publique, Epidemiology and Public Health, 2013;

61(supplement 3) ; 2013, S123-S125

50 Touraine M, Health inequalities and France's national health strategy. Lancet, 2014, 383(9923): 1101-2.

51 Peretti-Watel $\mathrm{P}$, La prévention primaire contribue-t-elle à accroître les inégalités sociales de santé ? Revue d'Epidémiologie et de Santé Publique, Epidemiology and Public Health, 61(supplement 3); august 2013, S158-S162

52 Trannoy A, Quels enseignements tirer des théories de la justice en matière d'inégalités de santé ? Revue d'Epidémiologie et de Santé Publique, Epidemiology and Public Health, 2013, 61(supplement 3): S153-S157

53 World Health Organization, Closing the health gap in a generation: health equity through action on the social determinants of health. Final report of the Commission on the Social Determinants of Health, Geneva, World Health Organization, 2008

54 Couffinhal A., Dourgnon P., Geoffard P.-Y., Grignon M., Jusot F., Lavis J., et al., « Politiques de réduction des inégalités de santé, quelle place pour le système de santé ? Un éclairage européen. Questions d'économie de la santé, 2005, $n^{\circ} 92$ : p. 1-6

55 Pickett K, Wilkinson R, The spirit level. Why greater equality makes societies stronger, $2011 \mathrm{Ed}$. Bloomsbury Press 